\title{
腐朽したスギ材に打込まれた釘の一面せん断耐力の推定
}

\author{
森 拓郎* 田中 圭** 河野孝太郎** \\ 中畑拓巳** 笨瀬佳之*** 栗﨑 宏****
}

\section{Estimation of Shear Strength of Nail Driven into Decayed Wood of Japanese Cedar Sugi}

by

\author{
Takuro MorI*, Kei TanaKa**, Kotaro Kawano**, \\ Takumi NaKahata**, Yoshiyuki YAnASE *** and Hiroshi KuRISAKI****
}

\begin{abstract}
This study was aimed at evaluating and estimating the shear strength properties of nailed wood (Sugi) connection damaged by decay. Steel and stainless steel nails were driven into specimens, and then the specimens were decayed by compulsion using cultured brown rot fungi (Fomitopsis palustris). The Pilodyn's penetration depth and the bearing strength were measured to estimate the shear strength of nailed connection damaged by decay. The single shear tests of nailed connection were conducted to investigate relationship between Pilodyn's penetration depth and shear strength. It was found that the stainless steel nails slightly decreased yield strength with increasing penetration depth. However, the steel nails showed an opposite tendency due to rust. The deeper the penetration depth caused the lower the bearing strength. The shear strength of decayed nailed joint was also compared with the estimated strength by the European Yield Theory (EYT) based on the bearing strength calculated from the penetration depth, and as results of both data showed good agreement. Thus, it was proposed $29 \mathrm{~mm}$ of Pilodyn's penetration depth as the threshold value for nailed connection using Sugi.
\end{abstract}

\section{Key words:}

Bio-deterioration, Bearing strength, Shear strength, Brown rot fungi, Pin penetration depth

\section{1 緒言}

木材が生物劣化を受けると残存している耐力は低下寸 るが，木造住宅などの構造物において実際にどれほど而 力や耐震性が低下寸るのかはわかっていない. そのため, 木造建築の耐震性能を評価するために用いられている標 準的な資料 ${ }^{1) 33}$ にも明確な記載は見られない。そこで，筆 者らは, 部材レベルでの検討を重ね, その結果として超 音波伝播速度やピロディン®の打ち込み深さによって, 部 材レベルでの耐力推定, また使用限度に関する閾值を決 定できる可能性を示唆した ${ }^{4), 5)}$. もちろん, 木質構造物は 部材レベルの劣化によって耐力が減少し，その機能が大 きく損なわれるが，最も耐力に大きな影響を与える箇所 は接合部である，そのため，接合部に焦点を当て木材の 生物劣化を踏まえた接合耐力の検討 ${ }^{6)}$, 7) や釷など接合具 単体 ${ }^{8)}$ の検討などの研究がある。また，釘自体の劣化か ら耐用年数について検討 ${ }^{9)} し た$ 研究などが行われてきて いる．特に釘は，古くから用いられている接合具である ため, その引き抜き耐力をもとに部材の性能を評価しよ うとする試み 10), 11)などもみられ, 釘自体については, 様々 な検討が行われてきている。これらの中で, 阿部の涙菌
による腐朽と針葉樹材の強度 ${ }^{12}$, , 高橋らの腐朽菌の種類 と強度劣化 ${ }^{13)}$, 十代田の腐朽を受けた各種木材の圧縮強 度と釗の引き抜き耐力 ${ }^{10)}$, いずれにも，樹種が異なるこ とによって生物劣化による耐力の低下や接合具の強度性 能の変化に差異があることが報告されている.

そこで本研究では，腐朽したスギ材に打ち込まれた釘 の一面せん断性能を推定することを目的として, 腐朽し たスギ材に打ち込まれた釘の一面せん断性能試験, 腐朽 した材を用いた支圧試験, これらを非破壞に推定するた めのピロディンを用いた打ち込多深さ計測などを行い, その関係を明らかにしたので報告する.さらに，これら の関係から検討した耐力推定方法について提案する.

\section{2 試験概要}

\section{1 劣化診断機器および測定項目}

本研究で劣化度を評価するために用いた診断機器は打 ち込み深さ測定器（エフティーエス社製 Pilodyn ${ }^{\circledR}$; 打ち 込みエネルギー $6.0 \mathrm{~J}$, 以下: 診断機器) である. 診断機器 は, 長さ $40 \mathrm{~mm} \phi 2.5 \mathrm{~mm}$ の鋼製ニードルをバネの一定の反 発力を用いて打ち込み, その深さを計測することで，表

$\dagger$ 原稿受理 平成 25年 8月 7日 Received Aug. 7, 2013

(C)2014 The Society of Materials Science, Japan

* 正 会 員 京都大学生存圈研究所 干611-0011 宇治市五ヶ庄

Res. Inst. for Sustainable Humanosphere, Kyoto Univ., Gokasho, Uji, 611-0011.

** 大分大学工学部福祉環境工学科 $\overline{7} 870-1192$ 大分市大字旦野原

Faculty of Eng., Oita Univ., Dannoharu, Oita, 870-1192.

*** 正 会 員 京都大学大学院農学研究科 $\overline{7} 606-8502$ 京都市左京区北白川追分町

Graduate School of Agri., Kyoto Univ., Sakyo-ku, Kyoto, 606-8502.

****富山県農林水産総合技術センター木材研究所 干939-0311 射水市黒河新

Forest Products Res. Inst. for Toyama Prefectural Agricultural, Forestry and Fisheries Res. Center, Kurokawashin, Imizu, 939-0311 
面付近の劣化度を診断する機器である、本報告における 打ち込夕深さの計測は，支圧試験体においては辺材側か ら，一面せん断試験体においては辺材および心材側から 放射方向（R 方向）に釷打ち込夕位置近傍で，一度ずつ実 施した。 また, 支圧試験体は試験後, 乾燥器にて $105^{\circ} \mathrm{C}$, 二日間で絶乾状態とした後，小片の重さを計測し，腐朽 後の容積密度および含水率を求めた.

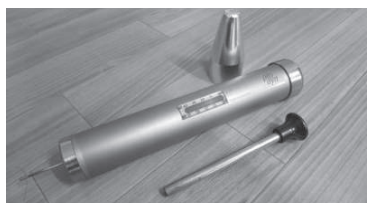

Fig.1 Pilodyn ${ }^{\circledR}$.

\section{2 腐朽操作および試験体概要}

Fig.2 に試験体調整の様子を示す。試験体には気乾密度 $365 \mathrm{~kg} / \mathrm{m}^{3}$, 変動係数 0.03 のスギ (Cryptomeria japonica) 材を用いた。腐朽操作は，富山県農林水産総合技術セン ター木材研究所において実施した。腐朽操作には，腐朽 速度が速く針葉樹において加害が激しいオオウズラタケ

(Fomitopsis palustris) を用いた。まず，腐朽菌を培養し たバーミキュライトの培地を $50 \times 50 \times 250 \mathrm{~mm}$ の試験体中 央部に接種し，約 4 週から 18 週の間，強制腐朽させた. 強制腐朽させた後，気乾状態まで乾燥させ，釘の一面せ ん断試験に供し，試験終了後の試験体より，中央部の腐 朽箇所から 1 体 (腐朽試験体)，端部の健全と思われる部 分から 1 体（コントロール試験体）の支圧試験体を採取 した.
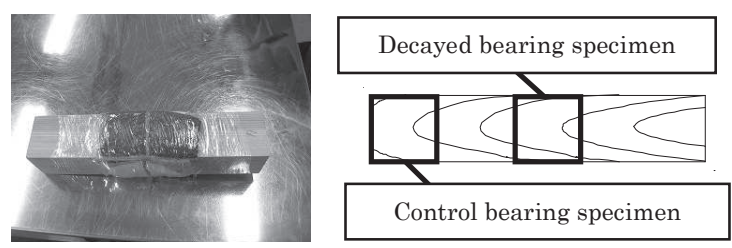

Fig.2 Decaying single shear joint specimen by brown rot fungi (Bearing test was carried out following shear test).

\section{3 支圧性能}

\section{1 支圧試験概要}

3.1 .1 支圧試験 Fig.3 に試験体形状および寸法を示す 支圧試験の加力用のピンは, 普通鉄丸くぎ N50 釘の釷頭 を削り，長さ $45.43 \mathrm{~mm}$ ，径 $2.75 \mathrm{~mm}$ とした。腐朽期間は 約 4 週から 18 週とし,コントロール試験体と腐朽試験体 を各 39 体用意した。試験時の含水率は概ね $12 \%$ であっ た.

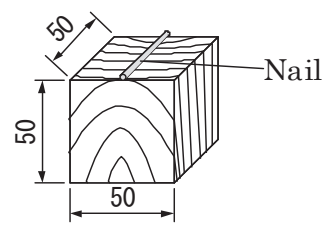

Fig.3 Dimension of specimen. (Unit in $\mathrm{mm}$ )
3.1 .2 支圧試験方法 Fig.4 に支圧試験の加力装置を示 す．支圧試験は試験体に溝を設けず，釘を Fig.4 に示す ように釷側面から押し込むように行い, 加力方向は繊維 平行方向とした，載荷は $100 \mathrm{kN}$ 万能試験機（インストロ ン社製）による単調載荷（載荷速度： $1.4 \mathrm{~mm} / \mathrm{min}$ ) で行 った，変位はクロスヘッドの移動と同じであるとし，ク ロスヘッド変位を 2 本のストレインゲージ式変位計にて 計測した。

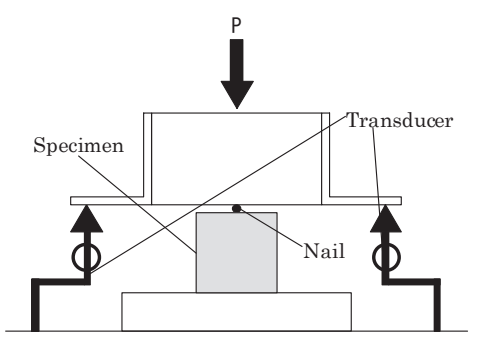

Fig.4 Set-up for bearing test.

\section{2 支圧性能評価}

3.2.1 診断機器による測定值と密度の関係 Fig.5 に支 圧試験体における診断機器の打ち込み深さと容積密度 の関係を示す. 多少のばらつきはあるものの打ち込夕深 さと密度には負の相関がみられた。このことから，打ち 込み深さの測定により密度低下の度合について診断す ることが可能であると考える。

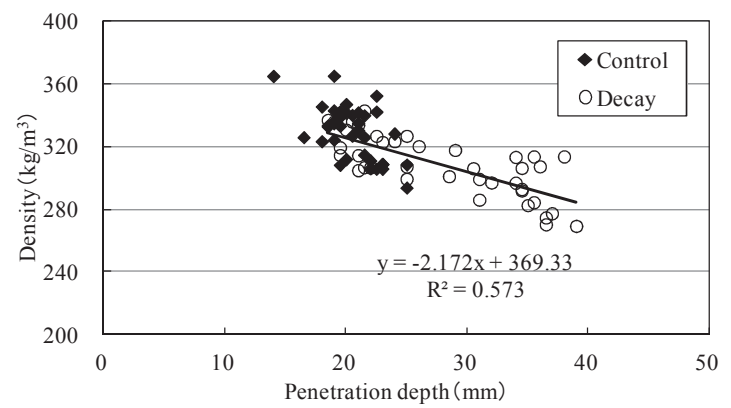

Fig.5 Relationship between penetration depth and density.

3.2.2 荷重変位関係 Fig.6 に支圧試験における荷重変 位関係を示す。腐朽試験体とコントロール試験体では, 腐朽試験体の方が比較的剛性が低くなる傾向がみられ た。これは，腐朽によって木材の支圧剛性が低下したた めと考えられる。

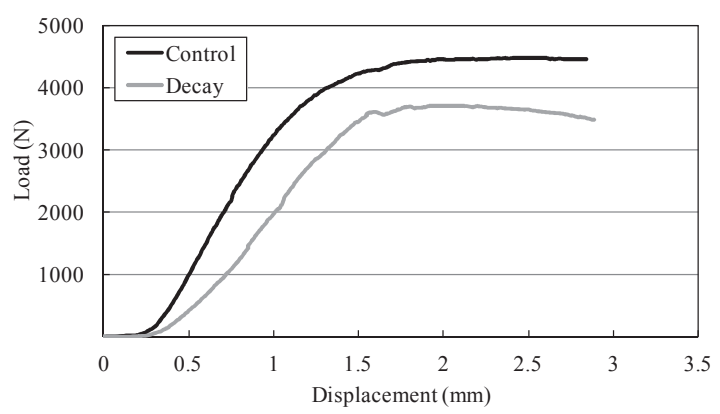

Fig.6 Relationship between load and displacement. 


\subsection{3 支圧強度と容積密度および診断機器による測定}

値の関係 Fig.7 に支圧試験における支圧強度と容積密 度の関係を示す. なお, ここでは, 約 $2.7 \mathrm{~mm}$ 変形時で加 力盤が試験体に触れることによって始まる急激な荷重 上昇を起こす前までの最大の值を最大荷重とした。そし て，その最大荷重を支圧面積である釘の見付面積で除し たものを支圧強度とした。図より，コントロール試験体， 腐朽試験体ともに密度が低下寸るに従い支圧強度が低 下寸る傾向がみられた。また腐朽試験体において，同程 度の密度でも支圧強度に大きな差のある試験体が多数 存在した.

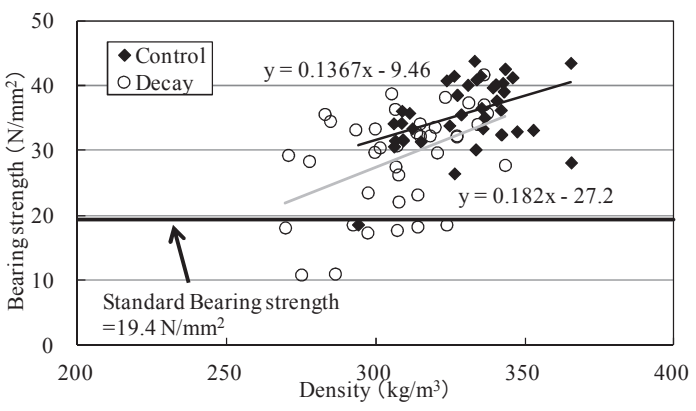

Fig.7 Relationship between density and bearing strength.

Fig.8 に支圧強度と打ち込み深さの関係を示す.コント ロールと腐朽試験体の值を区別せずに求めた累乗近似曲 線とスギの基準支圧強度 ${ }^{14)}$ も併せて示寸. 打ち込み深さ が深くなるに従い, 支圧強度が低くなる傾向がみられた。 また，支圧強度を大きく下回るのは打ち込み深さ $30 \mathrm{~mm}$ を超えたあたりであることがわかった。また，回帰曲線 を信頼水準 $75 \%$ の $5 \%$ 下限值に相当するようにノンパラ メトリック法で検討した結果，0.73 という低減係数が得 られた。この低減した曲線と基準支圧強度の交点は約 $29.3 \mathrm{~mm}$ であり，現行の基準支圧強度を満たす打ち込み深 さのしきい值として $29 \mathrm{~mm}$ を提案する。また，同図中に 戸田ら ${ }^{8)}$ がトドマツ (Abies sachalinensis) を用いて提案 している支圧強度の推定曲線も併せて示す。腐朽の程度 の違いも考えられるが，戸田らが提案した推定曲線は， 本研究の実験值と比較して低い值を示し，樹種による違 いが大きいことが確認された。

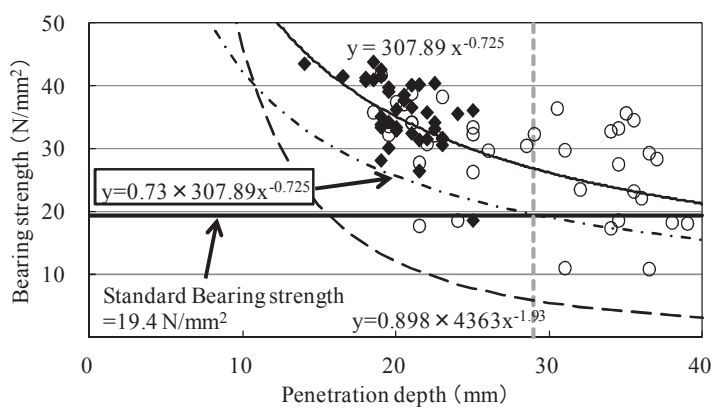

Fig.8 Relationship between penetration depth and bearing strength. Note: — average curve, - - proposal curve, - - Toda ${ }^{9}$,

\section{4 一面せん断性能}

4.1 一面せん断試験概要

4.1.1一面せん断試験体 Fig.9 に試験体形状, 寸法お よび釷打ち込み位置を示す。一面せん断試験の接合具に は長さ $45 \mathrm{~mm}$ の鉄釘（普通鉄丸くぎ $\mathrm{N} 45$, 径 $2.45 \mathrm{~mm}$ ) と ステンレス釘（径 $2.3 \mathrm{~mm}$ ）を，1 体の試験体に対して心 材側と辺材側から各 1 本ずつ，釷頭の下を $3 \mathrm{~mm}$ 残すよ うに打ち込んだ。腐朽期間は 4 週， 6 週，10 週，14 週， 18 週とし, 各 4 体とした. 都合, 試験体 1 体につき 4 つ のデータが得られることとなる.

4.1.2 一面せん断試験方法 Fig.10 に一面せん断試験 の加力装置を示す. $2000 \mathrm{kN}$ 万能試験機（島津製作所製） を用いて試験体を固定し, 図の治具を引張ることで引張 型による単調載加（載荷速度 : $1.0 \mathrm{~mm} / \mathrm{min}$ ）の一面せん 断試験を行った. 荷重の計測には $2 \mathrm{kN}$ のロードセルを用 いた。

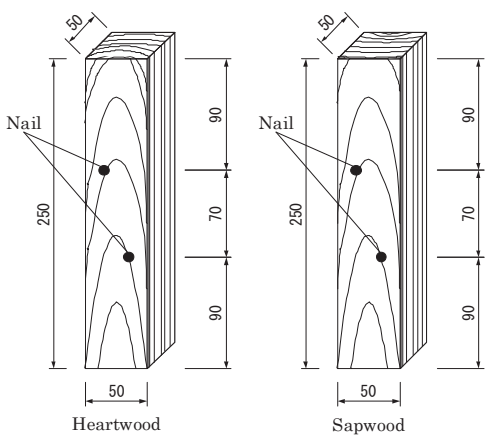

Fig.9 Dimension of specimens and locations of nails. (Unit in $\mathrm{mm}$ )

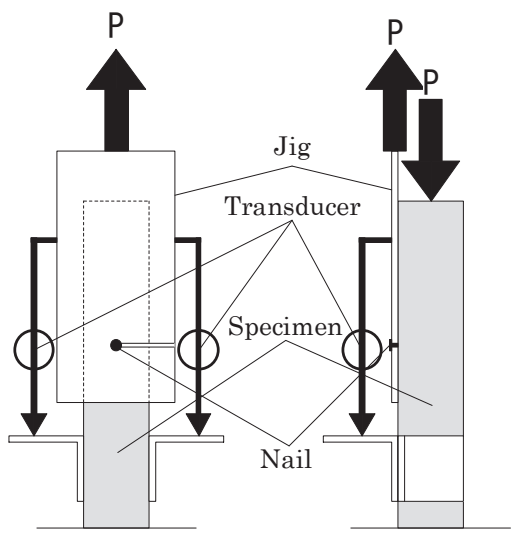

Fig.10 Set-up for single shear nailed connection test.

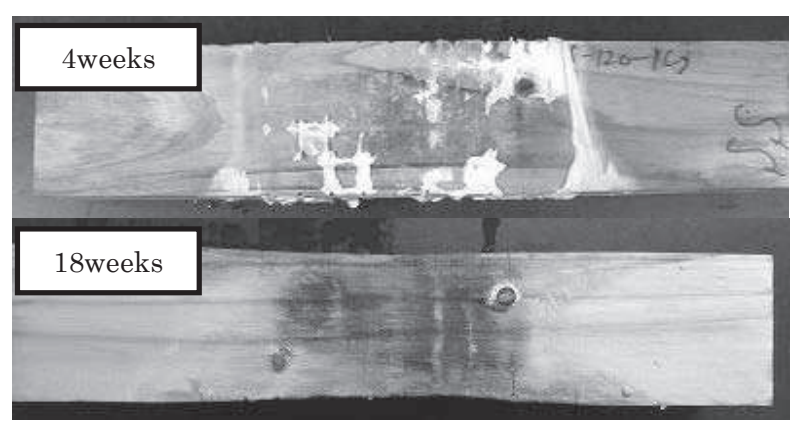

Fig.11 State of decay (wet condition). 


\section{2 一面せん断試験体の劣化性状}

Fig.11 に一面せん断試験体の劣化性状を示寸. 4 週から 18 週の腐朽期間の違いは, 目視では側部や表裏部の瘦せ, また触診において表面部の軟化度合いの違いなどがみら れた。強制腐朽後，気乾状態まで乾燥させることで，腐 朽部分に褐色腐朽菌による被害特有の繊維を分断するき 裂が多く発生した。また, 鉄釷では錆が多くみられたが, ステンレス釘では錆がほとんど確認されなかった.

\section{3 一面せん断性能評価}

4.3.1 破壊性状 Fig.12 に破壊性状を示寸. 鉄釘では試 験の最終段階において釘頭が破断するものがほとんど であり，ステンレス釘では釘の曲げ変形がすべての試験 体で見られた。破壊性状については，釘の種類による違 いはみられたものの，打ち込み面の辺心材による違い， 腐朽の有無による差異はみられなかった。
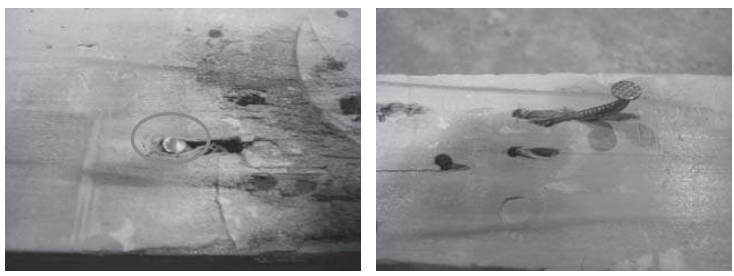

Fig.12 Failure mode of shear test (Left: SS, Right: SUS)

4.3.2 荷重変位関係 Fig.13 と Fig.14 に一面せん断試験 の荷重变位関係の一例を示す．鉄釘の腐朽試験体におい ては釘頭の破断により終局破壊に至るため，終局破壊時 の変位がコントロール試験体に比べて小さくなる傾向 がみられた。これは鉄釷が錆びたためによる断面の減少 によると考えられる。また，過去の報告 ${ }^{9}$,15) と同様の錆 によると考えられる耐力の上昇が鉄釘試験体において みられた。しかし，ステンレス釷ではそのような傾向は みられず，コントロール試験体と腐朽試験体の挙動に大 きな違いはみられなかった。なお，200～400N 辺りにみ られる変曲点は加力治具と母材との境界近傍での釘頭 付近の局部的な曲げ降伏によるものではないかと考え ている.

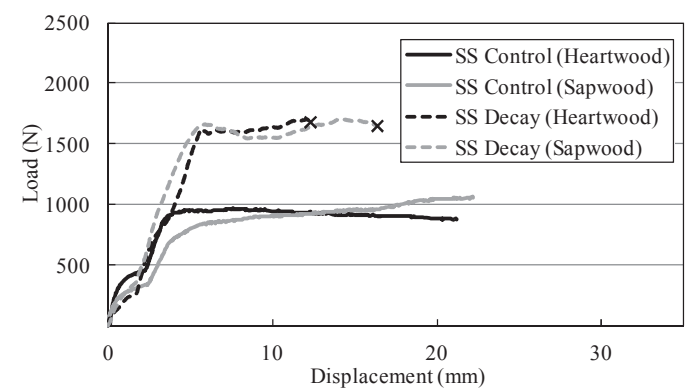

Fig.13 Relationship between load and displacement (SS: Steel nail) .

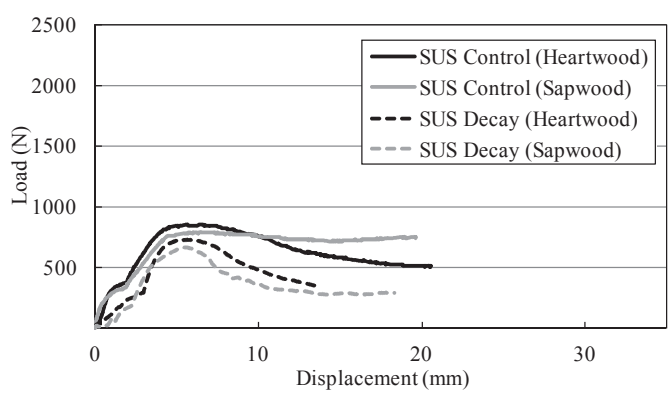

Fig.14 Relationship between load and displacement (SUS: Stainless steel nail)

\subsection{3 一面せん断耐力と診断機器による測定値の関係}

Fig.15 と Fig.16 に腐朽期間と打ち込み深さの関係を示 す. 辺材側からの打ち込みでは，腐朽期間が長くなるに 従い，打ち込み深さが深くなる傾向がみられ，打ち込み 深さが最大となった 14 週目の值は，腐朽初期段階である 4 週目の值から約 40\%増加した。しかし，心材側からの 打ち込みでは，4 週目から 14 週目までの増加率は約 $12 \%$ であった。 これは，辺材側の方が腐朽の進行が速く，加 害が激しかったためと考えている。また，18 週目の值が 小さくなった理由は腐朽菌の活性が低かったことが考え られるが，断定できるデータはなかった。

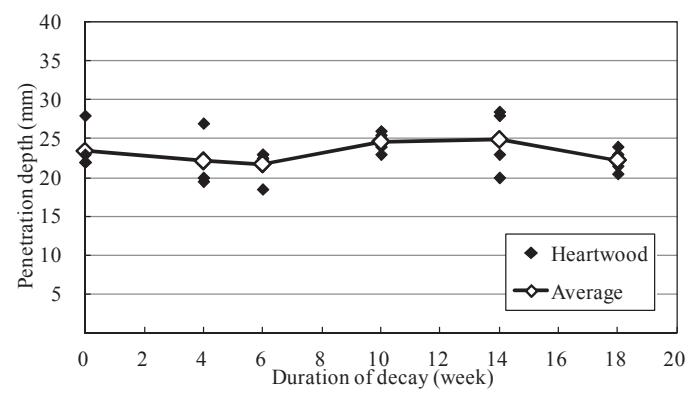

Fig.15 Relationship between penetration depth and duration of decay (Heartwood).

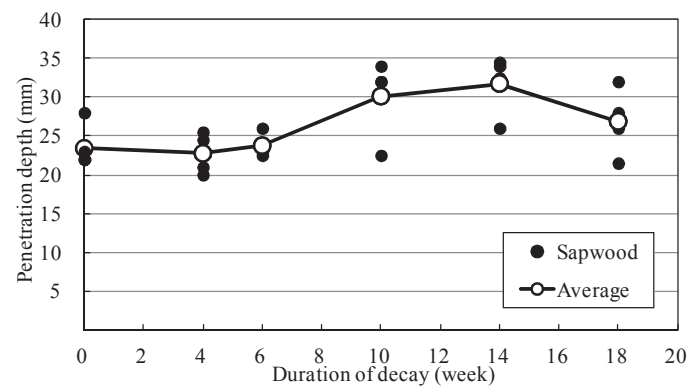

Fig.16 Relationship between penetration depth and duration of decay (Sapwood).

Fig.17 と Fig.18 に腐朽期間と降伏耐力の関係を示す. 鉄 釘を打ち込んだ試験体では，腐朽期間が長くなるに従い， 降伏耐力が高くなる傾向がみられた。これは，試験体内 で鉄釬が錆びることによる効果だと考えられ，他の研究 においても腐食の初期段階では同様の結果が報告されて いる ${ }^{9,15)}$.しかし，ステンレス釷を打ち込んだ試験体では 
そのような傾向はみられず，腐朽期間が長くなるに従い， 降伏耐力がわずかに低下寸る傾向がみられた。

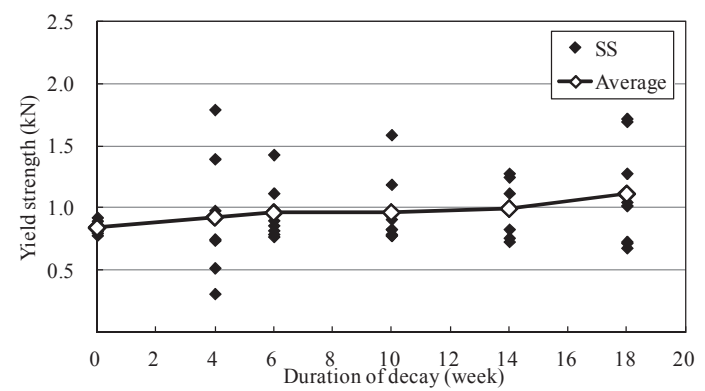

Fig.17 Relationship between yield strength and duration of decay (SS: Steel nail).

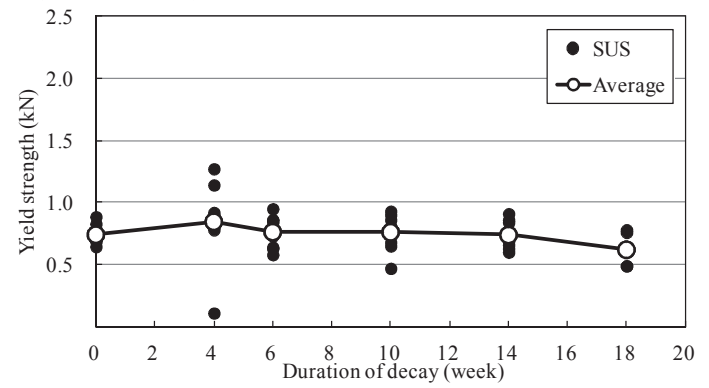

Fig.18 Relationship between yield strength and duration of decay (SUS: Stainless steel nail).

Fig.19 F Fig.20 に一面せん断試験における降伏耐力と 打ち込み深さの関係を示寸。降伏耐力は, 完全弾塑性近 似モデル ${ }^{16)}$ による $P_{y}$ を用いた. 両方の釷ともに正負逆の 傾向を示したが，ともに傾きがほぼ 0 に近く，相関係数 も低い值となった。また，ステンレス釷が鉄釘と比較し て多少ばらつきが小さかった.

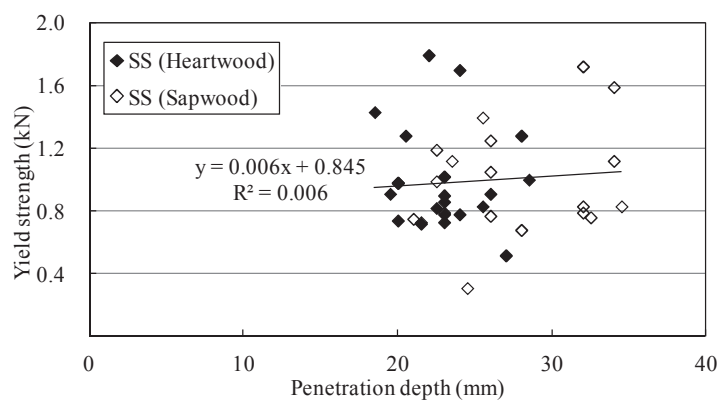

Fig.19 Relationship between yield strength and penetration depth (SS: Steel nail).

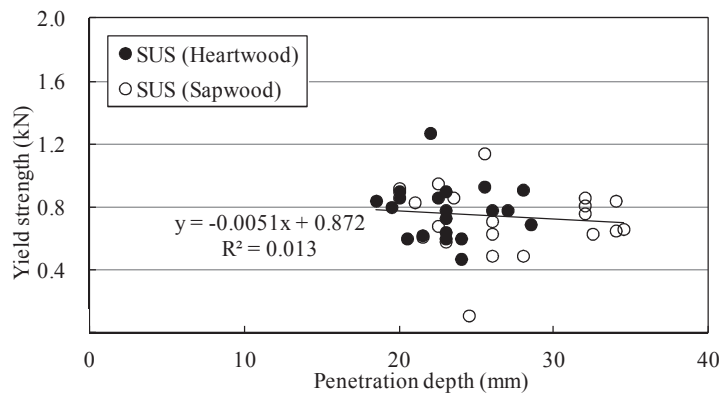

Fig.20 Relationship between yield strength and penetration depth (SUS: Stainless steel nail).

\subsection{4 木材腐朽後の一面せん断耐力の推定}

現行の木質構造設計規準 ${ }^{16)}$ に則り, ヨーロッパ型降伏 理論（EYT）に基づいて釷接合の降伏せん断耐力を求め るとともに，実験結果との比較を行った.

EYT の降伏せん断耐力算定式は, 以下のようになる.

$$
P_{y}=F_{e} \times d^{2} \times \sqrt{\frac{2}{3} \times \gamma}
$$

ここで， $P_{y}$ : 単位接合部の降伏せん断耐力（N)

$F_{e}$ : 主材の基準支圧強度 $\left(\mathrm{N} / \mathrm{mm}^{2}\right)$

$d:$ 接合具径 $(\mathrm{mm}) \mathrm{SS}: 2.45 \mathrm{~mm}$ 、SUS $: 2.3 \mathrm{~mm}$

$\gamma$ : 接合具の基準材料強度と主材の

基準支圧強度の比 $\left(F / F_{e}\right)$

$F$ : 接合具の基準材料強度 $\left(\mathrm{N} / \mathrm{mm}^{2}\right) 690 \mathrm{~N} / \mathrm{mm}^{2}$

本研究では，腐朽の程度に応じた釘接合の降伏せん断 耐力を推定するために，第 3 章の打ち込み深さと支圧強 度の関係より得た累乗近似曲線の式により, 打ち込み深 さごとの支圧強度を求め, これを用いて鋼板添え板釘接 合の降伏せん断耐力 $P_{y}$ を EYT 算定式から計算した。

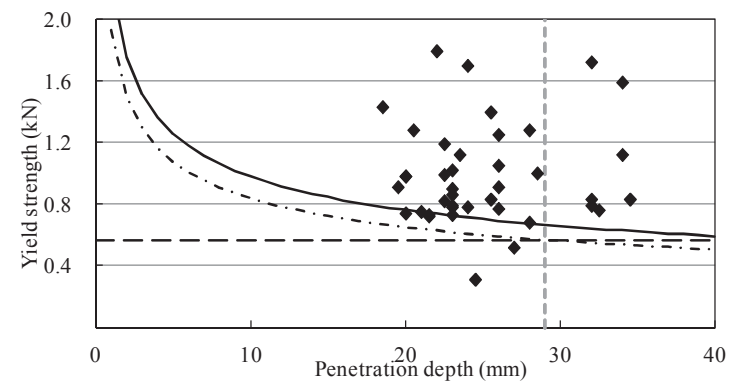

Fig.21 Relationship between yield strength and duration of decay (SS: Steel nail).

Note: — using the average of bearing strength, - - - using the proposed formula of bearing strength for design, - - using the standard bearing strength.

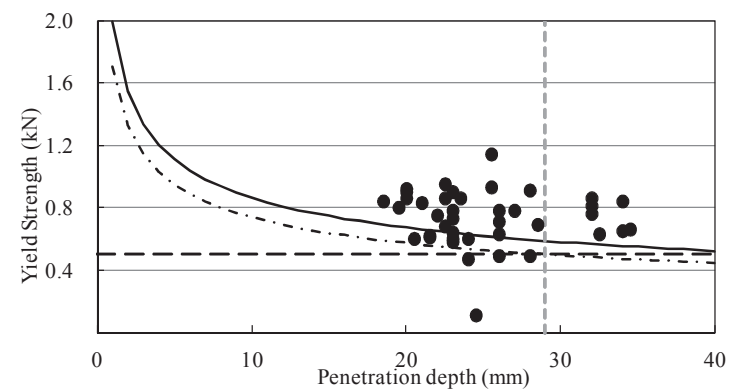

Fig.22 Relationship between yield strength and duration of decay (SUS: Stainless steel nail).

Note: — using the average of bearing strength, - - -using the proposed formula of bearing strength for design, - - using the standard bearing strength.

打ち込み深さと EYT 算定式で推定した降伏せん断耐力 との関係曲線を, Fig.21 と Fig.22 に鉄釷とステンレス釷と に分けて示す．鉄釷では実験值のばらつきが大きいもの の, 両図とも支圧強度の平均值を用いた EYT 算定式の推 定曲線は，概小実験の下限に相当していることが看取さ 
れる。また，提案式を代入した值はより安全側の評価を し，今回実施した釷の径に対して降伏耐力を満足するた めには $29 \mathrm{~mm}$ 以上の打ち込み深さが必要であることがわ かった。

\section{5 結 言}

腐朽したスギ材に打ち込まれた釷の一面せん断性能を 推定することを目的として，腐朽したスギ材に打ち込ま れた釷の一面せん断試験，腐朽した材を用いた支圧試験， これらを非破壊に推定するための診断機器を用いた打ち 込夕深さ計測を行い，これらの関係から検討した耐力推 定式を提案した。 その結果, EYT 算定式に支圧強度と打 ち込み深さの関係式を代入することで，打ち込み深さか らスギ材での鋼板添え板釘接合の降伏せん断耐力を推定 できることがわかった。また，本試験の範囲においてス ギ材における，現行の必要せん断耐力の閾值としては, 打ち込み深さ $29 \mathrm{~mm}$ が妥当であると考えた.

今後は，柱と土台の接合部などの耐力を評価していく ために，繊維直交方向加力における釘の一面せん断耐力 の推定值についても検討していく必要がある。また，本 検討は釷長さ $45 \mathrm{~mm}$ で実施しており，釘長さが変わると 診断機器の打ち込み深さとの関係が変わることが考えら れるため，長さをパラメータにした検討も必要である. 加えて，樹種の違いによる差が大きいことが確認された ため, 異なる樹種によるデータの蓄積が必要と考える.

本研究の一部は, 科学研究費補助金（基盤研究（A） 2246072 : 代表者 : 林康裕）により実施しました。実験に おいては，大分大学井上研究室の学生諸氏に多大な協力 をいただきました。また，京都大学生存圈研究所全国共 同利用研究・DOL/LSF の助成を受けました。ここに謝意 を表します。

\section{参 考 文 献}

1) Japan Wood Preserving Association, "Diagnosis manual of the fungi and the pest damage of residential house for strategist”, pp.98-110 (2004).

2) The Japanese Building Disaster Prevention Association, "Seismic diagnosis and reinforcement method for residential wooden house", pp.125-126, pp.312-330 (2006).

3) Japan Housing and Wood Technology Center, "The durability design and control of maintenance and deterioration diagnosis for residential wooden house", pp.105-129 (2002).

4) T. Mori, A. Kousoku, Y. Yanase, K. Komatsu, "Relationships between strength properties and density or ultrasonic velocity of timber attacked by termite", Journal of the Society of Materials Science, Japan, Vol.59, No.4, pp.297-302 (2010).

5) T. Mori, Y. Yanase, K. Tanaka, K. Kawano, Y. Noda, M. Mori, H. Kurisaki, and K. Komatsu, "Evaluation of compression and bending strength properties of wood damaged from bio-deterioration", Journal of the Society of Materials Science, Japan, Vol.62, No.4, pp.280-285 (2013).

6) H. Takiuchi, K. Sawata, T. Sasaki, Y. Okazaki, S. Doi, and Y. Iijima, "Embedding strength of wood exposed to decay fungi“, Mokuzaigakkaishi, Vol.53, No.1, pp.46-51 (2007).

7) H. Kurisaki, H. Nakatani, "Lowering of the bolted connection strength by 'OOUZURATAKE' decay", Collection of Annual Meeting of the Japan Wood Research Society, Vol.48, No.1, pp.443 (1998).

8) M. Toda, M. Mori, Y. Ohashi, and T. Hirai, "Effects of wood decay on the shear performance of nailed timber joint“, Mokuzaigakkaishi, Vol.56, No.1, pp.41-47 (2010).

9) H. Ishiyama, M. Koshihara, "Experimental study on the performance of the nailed joint with the rust: study on the structural performance of wooden house when deteriorated (Part1)“, Journal of Structural and Construction Engineering, Vol.74, No.646, pp.2281-2289 (2009).

10) S. Soshiroda, "Mokuzainofukyudotokugihikinuki tairyo kudotonokankei“, Reports of Architectural Institute of Japan, No.21, pp.147-150 (1953).

11) S. Soshiroda, "Mokuzaifukyudosokuteikinoshisakutoso nosokuteichi“, Reports of Architectural Institute of Japan, No.10, pp.297-300 (1951).

12) Y. Abe, "Decay of coniferous wood caused by Merulius lacrymans and their effect on the compressive strength of the wood", Hokkaido Ringyoushikennshuuhou, No.68, pp.23-36 (1959).

13) M. Takahashi, K. Nishimoto, "Studies on the mechanism of wood decay ( I): changes in strength of BUNA and SUGI wood as decay proceeds“, Wood Research, No.41, pp.75-89 (1967).

14) Architectural Institute of Japan, "Standard for structural design of timber structures", pp.223 (2006).

15) K. Kamiyama, K. Hijikuro, S. Yasu, "Kugisetugouno taikyuseini kansuru kenkyu", Collection of Architectural Institute of Japan Kanto Branch Architectural Research Meeting, No.50, pp.221-224 (1979).

16) Architectural Institute of Japan, "Standard for structural design of timber structures", pp.369 (2006). 